Animal Health Research Institute,

Dokki, Giza.

\title{
INCIDENCE OF PROTEOLYTIC AND LIPOLYTIC MOULDS AND YEASTS IN SOME READY TO EAT MEAT PRODUCTS
}

(With 7 Tables)

By

\author{
JEHAN M. OUF; NAGWA I.M. KHAFAGA \\ and E.S.E. SHABANA
}

(Received at 12/5/2010)

مدى تواجد الفطريات والخمائر المحللة للبروتينات والدهون فى منتجات اللحوم المعدة للأكل

\section{جيهان محمود عوف ، نجوى خفاجى ، السبي صلاح شبانة}

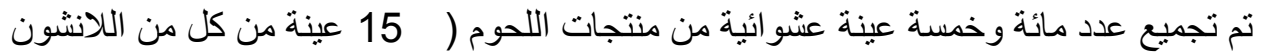

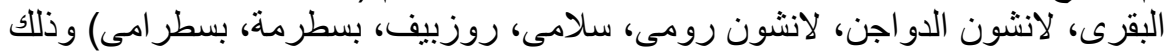

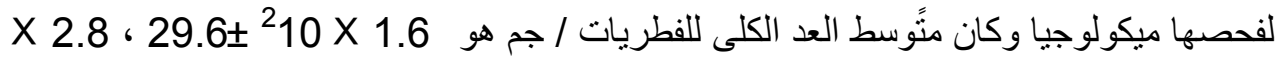

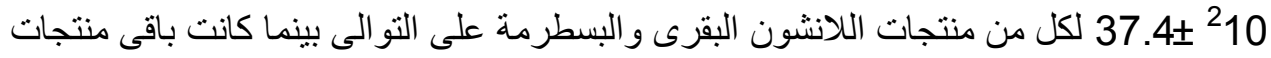

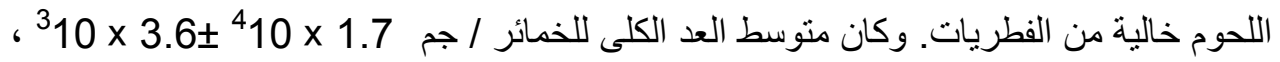

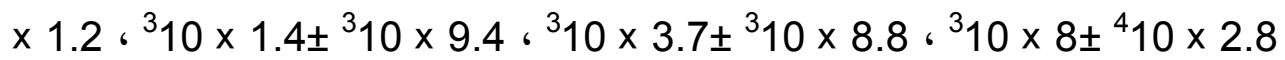

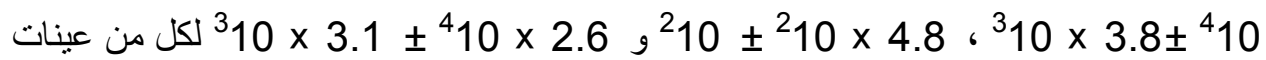

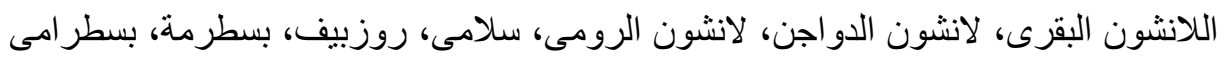

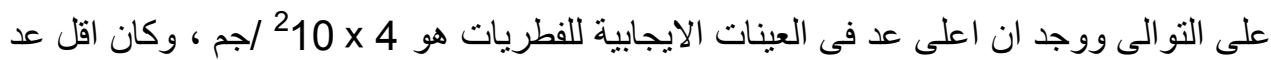

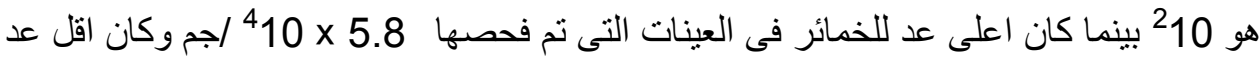

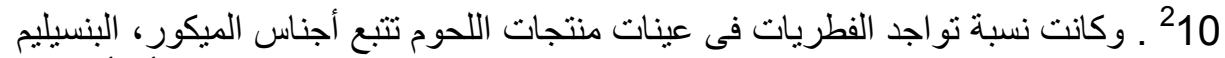

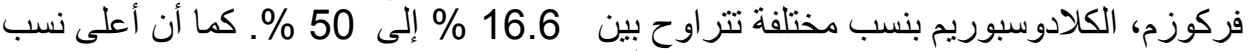

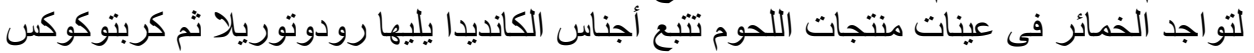

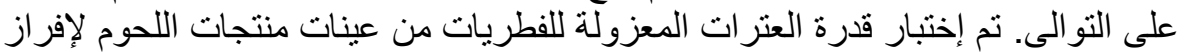
الإنزيمات المذيبة للبروتين والدهون. الفطريات و الخمائر وكذلك الإحتياطات الصحية اللازمة.

\section{SUMMARY}

A total of one hundred and five random samples of meat products (15each of beef luncheon, chicken luncheon, turkey luncheon, salami, rose beef, basterma and pastrami) were collected and subjected to mycological 
evaluation. Moulds could be detected only in beef luncheon and basterma where their mean counts were $1.6 \times 10^{2} \pm 29.6$ and $2.8 \times 10^{2} \pm 37.4 / \mathrm{gm}$ respectively. The mean total yeasts counts/gm were $1.7 \times 10^{4} \pm 3.6 \times 10^{3}$, $2.8 \times 10^{4} \pm 8 \times 10^{3}, 8.8 \times 10^{3} \pm 3.7 \times 10^{3}, 9.4 \times 10^{3} \pm 1.4 \times 10^{3}, 1.2 \times 10^{4} \pm$ $3.8 \times 10^{3}, 4.8 \times 10^{2} \pm 10^{2}$ and $2.6 \times 10^{4} \pm 3.1 \times 10^{3}$ for beef luncheon, chicken luncheon, turkey luncheon, salami, rose beef, basterma and pastrami samples respectively. It was found that the highest count of all examined positive samples for moulds was $4 \times 10^{2} / \mathrm{gm}$ and the lowest count was $10^{2}$ while for yeasts the highest count of the examined samples was $5.8 \times 10^{4} / \mathrm{gm}$ and the lowest count was $10^{2}$. Mucor spp., Penicillium vercosaum and Cladosporium spp. were isolated from the examined samples at varying percentages ranged from $16.6-50 \%$. The predominant species of yeasts isolated from beef luncheon, chicken luncheon, turkey luncheon, salami, rose beef, basterma and pastrami were Candida spp. followed by Rhodotorula spp. and then Crypotococcus species. The isolated moulds and yeasts from the examined samples were tested and evaluated for proteolytic and lipolytic activities. The public health significance of isolated moulds and yeasts as well as the sanitary precautions were mentioned.

Key words: Meat products, moulds, yeasts, proteolytic and lipolytic activities.

\section{INTRODUCTION}

A wide variety of meat products of reduced water activity $\left(\mathrm{a}_{\mathrm{w}}\right)$ are manufactured around the world. These products are more or less shelf stable depending on the ingredients and the process used (APHA, 1992).

Red meat processors are actively looking for reasonable interventions that minimize the risk of introducing undesirable microorganisms and bacterial pathogens from contaminated raw carcasses into processed meats (Surve et al., 1991).

Pastrami is a process that involves spicing of meat, brine curing, smoking it and, finally, steaming it until the connecting tissues within the meat break down into gelatins. Although beef navels are the traditional cut of meat for making pastrami, it is now common to see pastrami made from beef brisket, beef round and turkey. Pastrami was created as a method for preserving meat before modern refrigeration. Traditional New York pastrami is made from the navel end of the brisket. It is cured in brine, coated with a mix of spices such as garlic, coriander, black pepper, paprika, cloves, allspice, mustard seed and smoked.

Salami was thus all kind of salted meats. The Italian tradition of cured meats including several styles, the word salami soon specialized to 
indicate only the most popular kind, made with ground, salted and spiced meat forced into animal gut with an elongated and thin shape, then left to undergo some kind of fermentation process. A traditional salami, with its typical marbled appearance, is made from one or more of the following meats: pork, chopped beef (particularly veal), venison, poultry (especially turkey), and horse (chester). Additional ingredients may include: minced fat, wine, wheat, corn starch, salt, various herbs, spices and vinegar. The raw meat mixture is usually allowed to ferment for a day and then the mixture is either stuffed into an edible natural or non-edible artificial casing then hung to cure. The casings are often treated with an edible mold (Penicillium) culture as well. The mould is desired as it imparts flavor and prevents spoilage during the curing process. Salami is cured in warm, humid conditions in order to encourage growth of the bacteria involved in the fermentation process. Sugar is added as a food source for the bacteria during the curing process. Lactic acid is produced by the bacteria as a waste product, lowering the $\mathrm{pH}$ and coagulating and drying the meat.

Spoilage development is a complicated biological event, which needs to be studied at the species and biotype level. Certain microbial taxa may be differently influenced by the specific storage conditions, and different microbial species may unpredictably develop during meat storage, thus influencing the time and type of spoilage development (Ercolini et al., 2006).

Moulds and yeasts grow at a wide range of temperature and $\mathrm{pH}$ values, resulting in spoilage of the product (Pitt and Hocking, 1997). Their count is used as an index of storability and sanitary quality of the product. Such moulds and yeasts can cause gas, off flavor and rancidity or other flavor defects due to their proteolytic activity (Viljoen and Greyling, 1995).

The traditional source of moulds on raw dry sausages is the natural house mycoflora. This often consistes of heterogeneous molds composed of representatives of different genera and species (Berwal and Dinchev, 1991). Many of these moulds are undesirable and may lead to serious problems for both the consumer and the producer. Some of these molds are capable of producing mycotoxins (Lopez Diaz et al., 2001).

Yeast, like moulds, contributes a small, but definite part of the natural microflora of meat, although dry-cured meat products are frequently contaminated with yeast, with counts usually low in comparison to those of bacteria (Cook, 1995).

Growth of commonly occurring filamentous fungi in foods may result in production of toxins known as mycotoxins, which can cause a variety of diseases in humans, from allergic responses to immunosuppression and cancer. The most important mycotoxins are 
aflatoxins, ochratoxin A and zearalenone. (Pitt, 2000; CAST, 2003 and Garcia and Heredia, 2006).

Mycotoxins are widespread in many countries, especially in tropical and subtropical regions where temperature and humidity conditions are optimal for growth of moulds and for production of toxins, so they are found in a wide variety of agricultural products (such as corn, wheat, soya beans and spices), and animal feeds, as well as meat products (including cured meats, sausages and chicken meat) as a result of carryover from contaminated animal feed (Takahashi-Ando et al., 2004 and Cavaliere et al., 2006).

All AFs are chronically toxic to varying degrees. Aflatoxin $B_{1}$ is considered to be among the most potent carcinogens known and has been linked epidemiologically with cases of human liver cancer in a number of developing countries (Aikins and Norman, 1998).

Carcinogenic, mutagenic and teratogenic effects of $\mathrm{AF} \mathrm{B}_{1}$ have been reported for several animal species, and in humans (Sabbioni and Sepai, 1998).

This study was undertaken to secure the prevalence of moulds and yeasts in some meat products as well as to monitor the proteolytic and lipolytic activities of such moulds and yeasts.

\section{MATERIALS and METHODS}

\section{1 - Collection of samples:}

One hundred and five samples (15 each of packed and unpacked beef luncheon, chicken luncheon, turkey luncheon, salami, rose beef, basterma and pastrami)) were collected from groceries and supermarkets in Cairo and Giza governorates. The samples were transferred to the laboratory with undue delay, where they were subjected to mycological investigation.

\section{2 - Preparation of the samples:}

The technique adopted was that recommended by APHA (1992). Ten gms from each sample were carefully and aseptically weighed and homogenized with $90 \mathrm{ml}$ of sterile $0.1 \%$ peptone water(Oxoid CM9) for about 2 min. using sterile homogenizer bags (in stomacher lab. Blender 400, Seward Lab. Serial No. 30469 type BA 7021, London). Ten fold serial dilutions were done in a manner to obtain a suitable number of fungal colonies which could be easily counted.

\section{3 - Estimation of total mould and yeast count:}

The technique described by Bailey and Scott (1998) was adopted. Duplicate plates of Sabouraud dextrose agar medium (containing $0.05 \mathrm{mg}$ of chloramphenicol per $\mathrm{ml}$ ) were inoculated each with $1 \mathrm{ml}$ from the 
prepared serial dilutions. Inoculated plates were incubated at $25^{\circ} \mathrm{C}$ for 5 days. The total yeast and mould counts per gram of the products were then calculated and recorded.

\section{4 - Isolation and identification of mould and yeast}

Suspected mould isolates were identified according to Pitt and Hocking (1997). Isolated moulds were cultured onto Malt extract plates for 3-5 days at $25^{\circ} \mathrm{C}$ then identified macroscopically and microscopically. Suspected yeasts isolates were identified according to Koneman et al. (1978); Finegold and Martin (1982).

\section{5 - Proteolytic activity of moulds and yeasts (O'reilly and Day, 1983):}

Each mould or yeast isolate was inoculated on the surface of skim milk agar in which skim milk was added just before pouring the medium into the Petri- plates. The plates were incubated at $28^{\circ} \mathrm{C}$ for 7 days. After the incubation period, the clear zones of hydrolysis were measured and recorded.

6 - Lipolytic activity of moulds and yeasts was determined according to the technique recommended by Koburger and Jacger (1987). Each mould or yeast isolate was inoculated on the surface of Tributyrin agar plates. The plates were incubated at $30^{\circ} \mathrm{C}$ for 3 days, the medium appeared opaque but lipolytic colonies were surrounded by a clear zone.

\section{RESULTS}

Table 1: Statistical analytical results of moulds and yeasts count of meat products samples $(\mathrm{n}=15)$

\begin{tabular}{|c|c|c|c|c|c|c|c|c|}
\hline \multirow{4}{*}{ samples } & \multicolumn{8}{|c|}{ Fungi } \\
\hline & \multicolumn{4}{|c|}{ Mould } & \multicolumn{4}{|c|}{ Yeast } \\
\hline & \multicolumn{2}{|c|}{$\begin{array}{l}\text { Positive } \\
\text { samples }\end{array}$} & \multicolumn{2}{|c|}{ Level } & \multicolumn{2}{|c|}{$\begin{array}{l}\text { Positive } \\
\text { samples }\end{array}$} & \multicolumn{2}{|c|}{ Level } \\
\hline & No & $\%$ & Range & Mean \pm SE & No & $\%$ & Range & Mean \pm SE \\
\hline $\begin{array}{l}\text { Beef } \\
\text { luncheon }\end{array}$ & 3 & 20 & $10^{2}-2 \times 10^{2}$ & $\begin{array}{c}1.6 \times 10^{2} \\
\pm 29.6\end{array}$ & 15 & 100 & $\begin{array}{l}8 \times 10^{2}- \\
3.1 \times 10^{4}\end{array}$ & $\begin{array}{l}1.7 \times 10^{4} \\
\pm 3.6 \times 10^{3}\end{array}$ \\
\hline $\begin{array}{l}\text { Chicken } \\
\text { luncheon }\end{array}$ & - & - & - & - & 10 & 66.6 & $\begin{array}{l}1.5 \times 10^{3}- \\
7 \times 10^{4}\end{array}$ & $\begin{array}{l}2.8 \times 10^{4} \\
\pm 8 \times 10^{3}\end{array}$ \\
\hline $\begin{array}{l}\text { Turkey } \\
\text { luncheon }\end{array}$ & - & - & - & - & 15 & 100 & $\begin{array}{l}5.4 \times 10^{3}- \\
7 \times 10^{4}\end{array}$ & $\begin{array}{l}8.8 \times 10^{3} \\
\pm 3.7 \times 10^{3}\end{array}$ \\
\hline Salami & - & - & - & - & 15 & 100 & $\begin{array}{l}4.4 \times 10^{3}- \\
2.5 \times 10^{4}\end{array}$ & $\begin{array}{l}9.4 \times 10^{3} \pm \\
1.4 \times 10^{3}\end{array}$ \\
\hline Rose beef & - & - & - & - & 15 & 100 & $\begin{array}{l}1.5 \times 10^{3}- \\
5 \times 10^{4}\end{array}$ & $\begin{array}{l}1.2 \times 10^{4} \pm \\
3.8 \times 10^{3}\end{array}$ \\
\hline Basterma & 5 & 33.3 & $\begin{array}{r}2 \times 10^{2}- \\
4 \times 10^{2} \\
\end{array}$ & $\begin{array}{c}2.8 \times 10^{2} \pm \\
37.4 \\
\end{array}$ & 14 & 93.3 & $\begin{array}{l}10^{2}- \\
1.3 \times 10^{3}\end{array}$ & $\begin{array}{l}4.8 \times 10^{2} \pm 1 \\
0^{2}\end{array}$ \\
\hline Pastrami & - & - & - & - & 15 & 100 & $\begin{array}{l}10^{4}- \\
5.8 \times 10^{4}\end{array}$ & $\begin{array}{l}2.6 \times 10^{4} \pm \\
3.1 \times 10^{3}\end{array}$ \\
\hline
\end{tabular}


Table 2: Incidence of moulds isolated from the examined meat products samples

\begin{tabular}{|c|c|c|c|c|c|c|c|c|c|c|c|c|c|c|c|c|}
\hline \multirow{3}{*}{ Mould species } & \multicolumn{16}{|c|}{ Meat Products } \\
\hline & \multicolumn{2}{|c|}{$\begin{array}{c}\text { Beef } \\
\text { luncheon }\end{array}$} & \multicolumn{2}{|c|}{$\begin{array}{l}\text { Chicken } \\
\text { luncheon }\end{array}$} & \multicolumn{2}{|c|}{$\begin{array}{l}\text { Turkey } \\
\text { Luncheon }\end{array}$} & \multicolumn{2}{|c|}{ Salami } & \multicolumn{2}{|c|}{$\begin{array}{l}\text { Rose } \\
\text { beef }\end{array}$} & \multicolumn{2}{|c|}{ Basterma } & \multicolumn{2}{|c|}{ Pastrami } & \multicolumn{2}{|c|}{ Total } \\
\hline & No & $\%$ & No & $\%$ & No & $\%$ & No & $\%$ & No & $\%$ & No & $\%$ & No & $\%$ & No & $\%$ \\
\hline $\begin{array}{l}\text { Penicillium } \\
\text { varcoasum }\end{array}$ & - & - & - & - & - & - & - & - & - & - & 4 & 26.66 & - & - & 4 & 26.66 \\
\hline Mucor spp. & 2 & 13.33 & - & - & - & - & - & - & - & - & - & - & - & - & 2 & 13.33 \\
\hline $\begin{array}{l}\text { Cladosporium } \\
\text { spp. }\end{array}$ & 3 & 20 & - & - & - & - & - & - & - & - & 3 & 20 & - & - & 6 & 40 \\
\hline Total & 5 & 33.33 & - & - & - & - & - & - & - & - & 7 & 46.66 & - & - & 12 & 79.99 \\
\hline
\end{tabular}

Table 3: Incidence of yeasts isolated from the examined meat products samples $(n=15)$

\begin{tabular}{|c|c|c|c|c|c|c|c|c|c|c|c|c|c|c|c|c|}
\hline \multirow{3}{*}{ Yeast species } & \multicolumn{16}{|c|}{ Meat Products } \\
\hline & \multicolumn{2}{|c|}{$\begin{array}{c}\text { Beef } \\
\text { luncheon }\end{array}$} & \multicolumn{2}{|c|}{$\begin{array}{l}\text { Chicken } \\
\text { luncheon }\end{array}$} & \multicolumn{2}{|c|}{$\begin{array}{c}\text { Turkey } \\
\text { Luncheon }\end{array}$} & \multicolumn{2}{|c|}{ Salami } & \multicolumn{2}{|c|}{$\begin{array}{l}\text { Rose } \\
\text { beef }\end{array}$} & \multicolumn{2}{|c|}{ Basterma } & \multicolumn{2}{|c|}{ Pastrami } & \multicolumn{2}{|c|}{ Total } \\
\hline & No & $\%$ & No & $\%$ & No & $\%$ & No & $\%$ & No & $\%$ & No & $\%$ & No & $\%$ & No & $\%$ \\
\hline $\begin{array}{l}\text { Candida } \\
\text { tropicalis }\end{array}$ & 10 & 6 & 5 & 3 & 3 & 1.8 & 9 & 5.4 & 7 & 4.2 & 3 & 1.8 & 7 & 4.2 & 44 & 26.5 \\
\hline $\begin{array}{l}\text { Candida } \\
\text { albicans }\end{array}$ & 9 & 5.4 & 4 & 2.4 & 2 & 1.2 & 3 & 1.8 & 8 & 4.8 & 3 & 1.8 & 3 & 1.8 & 32 & 19.3 \\
\hline $\begin{array}{l}\text { Candida } \\
\text { lipolitical }\end{array}$ & 7 & 4.2 & 3 & 1.8 & 4 & 2.4 & 5 & 3 & 5 & 3 & 3 & 1.8 & 5 & 3 & 32 & 19.3 \\
\hline $\begin{array}{l}\text { Cryptococcus } \\
\text { spp. }\end{array}$ & - & - & 2 & 1.2 & 3 & 1.8 & 6 & 3.6 & 5 & 3 & - & - & - & - & 16 & 9.6 \\
\hline $\begin{array}{l}\text { Rhodotorula } \\
\text { spp. }\end{array}$ & 9 & 5.4 & 6 & 3.6 & 6 & 3.6 & 7 & 4.2 & 5 & 3 & 6 & 3.6 & 3 & 1.8 & 42 & 25.3 \\
\hline Total & 35 & 21 & 20 & 12 & 18 & 10.8 & 30 & 18 & 30 & 18 & 15 & 9 & 18 & 10.8 & 166 & 100 \\
\hline
\end{tabular}


Table 4: Proteolytic activity of isolated moulds from examined meat products samples ( $\mathrm{N} 0$ of isolates $=12$ )

\begin{tabular}{|c|c|c|c|c|c|c|c|c|c|c|c|c|c|c|}
\hline \multirow{3}{*}{ Mould species } & \multicolumn{14}{|c|}{ Meat Products } \\
\hline & \multicolumn{2}{|c|}{$\begin{array}{c}\text { Beef } \\
\text { luncheon }\end{array}$} & \multicolumn{2}{|c|}{$\begin{array}{l}\text { Chicken } \\
\text { luncheon }\end{array}$} & \multicolumn{2}{|c|}{$\begin{array}{l}\text { Turkey } \\
\text { luncheon }\end{array}$} & \multicolumn{2}{|c|}{ Salami } & \multicolumn{2}{|c|}{ Rose beef } & \multicolumn{2}{|c|}{ Basterma } & \multicolumn{2}{|c|}{ Pastrami } \\
\hline & No & + ve & No & $+v e$ & No & $+\mathrm{ve}$ & No & $\%$ & No & + ve & No & $+\mathrm{ve}$ & No & $+v e$ \\
\hline $\begin{array}{l}\text { Penicillium } \\
\text { vercoasum }\end{array}$ & - & - & - & - & - & - & - & - & - & - & 4 & 3 & - & \\
\hline Mисог spp. & 2 & 1 & - & - & - & - & - & - & - & - & - & - & - & - \\
\hline $\begin{array}{l}\text { Cladosporium } \\
\text { spp. }\end{array}$ & 3 & 2 & - & - & - & - & - & - & - & - & 3 & 1 & - & - \\
\hline Total & 5 & 41.6 & - & - & - & - & - & - & - & - & 7 & 58.4 & - & - \\
\hline
\end{tabular}

Table 5: Lipolytic activity of isolated moulds from the examined meat products samples ( $\mathrm{N} 0$ of isolates $=12$ )

\begin{tabular}{|c|c|c|c|c|c|c|c|c|c|c|c|c|c|c|}
\hline \multirow{3}{*}{ Mould species } & \multicolumn{14}{|c|}{ Meat Products } \\
\hline & \multicolumn{2}{|c|}{$\begin{array}{c}\text { Beef } \\
\text { luncheon }\end{array}$} & \multicolumn{2}{|c|}{$\begin{array}{l}\text { Chicken } \\
\text { luncheon }\end{array}$} & \multicolumn{2}{|c|}{$\begin{array}{c}\text { Turkey } \\
\text { luncheon }\end{array}$} & \multicolumn{2}{|c|}{ Salami } & \multicolumn{2}{|c|}{ Rose beef } & \multicolumn{2}{|c|}{ Basterma } & \multicolumn{2}{|c|}{ Pastrami } \\
\hline & No & $+\mathrm{ve}$ & No & $+\mathrm{ve}$ & $\mathrm{No}$ & $+\mathrm{ve}$ & No & + ve & No & + ve & $\mathrm{Nc}$ & $+\mathrm{ve}$ & No & + ve \\
\hline $\begin{array}{l}\text { Penicillium } \\
\text { vercoasum }\end{array}$ & - & - & - & - & - & - & - & - & - & - & 4 & 4 & & \\
\hline Mucor spp. & 2 & 2 & - & - & - & - & - & - & - & - & - & - & - & - \\
\hline $\begin{array}{l}\text { Cladosporium } \\
\text { spp. }\end{array}$ & 3 & 3 & - & - & - & - & - & - & - & - & 3 & 1 & - & - \\
\hline Total & 5 & 41.6 & - & - & - & - & - & - & - & - & 7 & 58.4 & - & - \\
\hline
\end{tabular}


Table 6: Proteolytic activity of isolated yeasts from the examined meat products samples $(n=15)$

\begin{tabular}{|c|c|c|c|c|c|c|c|c|c|c|c|c|c|c|c|c|}
\hline \multirow{3}{*}{ Yeast species } & \multicolumn{16}{|c|}{ Meat Products } \\
\hline & \multicolumn{2}{|c|}{$\begin{array}{c}\text { Beef } \\
\text { luncheon }\end{array}$} & \multicolumn{2}{|c|}{$\begin{array}{l}\text { Chicken } \\
\text { luncheon }\end{array}$} & \multicolumn{2}{|c|}{$\begin{array}{c}\text { Turkey } \\
\text { luncheon }\end{array}$} & \multicolumn{2}{|c|}{ Salami } & \multicolumn{2}{|c|}{ Rose beef } & \multicolumn{2}{|c|}{ Basterma } & \multicolumn{2}{|c|}{ Pastrami } & \multicolumn{2}{|c|}{ Total } \\
\hline & No & $+\mathrm{ve}$ & No & $+\mathrm{ve}$ & No & $+\mathrm{ve}$ & No & $+\mathrm{ve}$ & No & $+\mathrm{ve}$ & No & $+\mathrm{ve}$ & No & $+\mathrm{ve}$ & No & $+\mathrm{ve}$ \\
\hline $\begin{array}{l}\text { Candida } \\
\text { tropicalis }\end{array}$ & 10 & 7 & 5 & 4 & 3 & 2 & 9 & 5 & 7 & 5 & 3 & 2 & 7 & 4 & 44 & 29 \\
\hline $\begin{array}{l}\text { Candida } \\
\text { albicans }\end{array}$ & 9 & 4 & 4 & 3 & 2 & 1 & 3 & 1 & 8 & 7 & 3 & 3 & 3 & 2 & 32 & 21 \\
\hline $\begin{array}{l}\text { Candida } \\
\text { lipolitical }\end{array}$ & 7 & 6 & 3 & 2 & 4 & 2 & 5 & 2 & 5 & 3 & 3 & 2 & 5 & 4 & 32 & 21 \\
\hline $\begin{array}{l}\text { Cryptococcus } \\
\text { spp. }\end{array}$ & - & - & 2 & 1 & 3 & 2 & 6 & 5 & 5 & 3 & - & - & - & - & 16 & 11 \\
\hline $\begin{array}{l}\text { Rhodotorula } \\
\text { spp. }\end{array}$ & \begin{tabular}{|l|}
9 \\
\end{tabular} & 8 & 6 & 5 & 6 & 4 & 7 & 5 & 5 & 3 & 6 & 4 & 3 & 2 & 42 & 31 \\
\hline Total & 35 & 25 & 20 & 15 & 18 & 11 & 30 & 18 & 30 & 21 & 15 & 11 & 18 & 12 & 166 & 113 \\
\hline
\end{tabular}

Table 7: Lipolytic activity of isolated yeasts from examined meat products samples $(n=15)$

\begin{tabular}{|c|c|c|c|c|c|c|c|c|c|c|c|c|c|c|c|c|}
\hline \multirow{3}{*}{$\begin{array}{c}\text { Yeast } \\
\text { species }\end{array}$} & \multicolumn{16}{|c|}{ Meat Products } \\
\hline & \multicolumn{2}{|c|}{$\begin{array}{c}\text { Beef } \\
\text { luncheon }\end{array}$} & \multicolumn{2}{|c|}{$\begin{array}{l}\text { Chicken } \\
\text { luncheon }\end{array}$} & \multicolumn{2}{|c|}{$\begin{array}{c}\text { Turkey } \\
\text { luncheon }\end{array}$} & \multicolumn{2}{|c|}{ Salami } & \multicolumn{2}{|c|}{$\begin{array}{l}\text { Rose } \\
\text { beef }\end{array}$} & \multicolumn{2}{|c|}{ Basterma } & \multicolumn{2}{|c|}{ Pastrami } & \multicolumn{2}{|c|}{ Total } \\
\hline & No & $+\mathrm{ve}$ & No & $+\mathrm{ve}$ & No & $+\mathrm{ve}$ & No & $+\mathrm{ve}$ & No & $+\mathrm{ve}$ & No & + ve & No & $+\mathrm{ve}$ & No & $+\mathrm{ve}$ \\
\hline $\begin{array}{l}\text { Candida } \\
\text { tropicalis }\end{array}$ & 10 & 10 & 5 & 4 & 3 & 3 & 9 & 6 & 7 & 6 & 3 & 3 & \begin{tabular}{|l|}
7 \\
\end{tabular} & 6 & 44 & 38 \\
\hline $\begin{array}{l}\text { Candida } \\
\text { albicans }\end{array}$ & 9 & 8 & 4 & 4 & 2 & 1 & 3 & 2 & 8 & 5 & 3 & 2 & 3 & 2 & 32 & 24 \\
\hline $\begin{array}{l}\text { Candida } \\
\text { lipolitical }\end{array}$ & 7 & 7 & 3 & 3 & 4 & 4 & 5 & 4 & 5 & 4 & 3 & 2 & 5 & 5 & 32 & 29 \\
\hline $\begin{array}{l}\text { Cryptococcus } \\
\text { spp. }\end{array}$ & - & - & 2 & 2 & 3 & 2 & 6 & 5 & 5 & 4 & - & - & - & - & 16 & 13 \\
\hline $\begin{array}{l}\text { Rhodotorula } \\
\text { spp. }\end{array}$ & 9 & 9 & 6 & 5 & 6 & 6 & 7 & 3 & 5 & 5 & 6 & 2 & 3 & 1 & 42 & 31 \\
\hline Total & 35 & 34 & 20 & 18 & 18 & 16 & 30 & 20 & 30 & 24 & 15 & 9 & 18 & 14 & 166 & 135 \\
\hline
\end{tabular}




\section{DISCUSSION}

Protein hydrolyzing microorganisms may produce a variety of odour and flavor defects particularly when contamination is high so it is necessary to give full consideration of spoilage microorganisms not only bacteria but also the mould and yeasts. The same consideration must be given to lipolytic fungi as it widely spread in nature and are heat resistant and their activity withstand in foods for long period even at low temperature (Lashin, 2003).

Presence of mould and yeast in meat and meat products indicates bad hygienic measures in the processing and handling of fresh meat and meat products (Abdel-Rahman et al., 1984).

Table 1 showed that moulds could be detected only in beef luncheon and basterma where the mean count values were $1.6 \times 10^{2} \pm 29.6$ and $2.8 \times 10^{2} \pm 37.4$ respectively On the other hand the mean total yeast count/gm were $1.7 \times 10^{4} \pm 3.6 \times 10^{3}, 2.8 \times 10^{4} \pm 8 \times 10^{3}, 8.8 \times 10^{3} \pm 3.7 \times 10^{3}$ $, 9.4 \times 10^{3} \pm 1.4 \times 10^{3}, 1.2 \times 10^{4} \pm 3.8 \times 10^{3}, 4.8 \times 10^{2} \pm 10^{2}$ and $2.6 \times 10^{4} \pm$ $3.1 \times 10^{3}$ for beef luncheon, chicken luncheon, turkey luncheon, salami, rose beef, basterma and pastrami samples respectively.

Contamination with yeasts and moulds and their toxins constitute a public health hazard, obviously it is of an importance to prevent mould growth to stop toxin production through preventing the natural contamination of raw materials, storage food under conditions which prevent mould growth, strict hygienic measures and regulations should be imposed during processing, packing and transportation (El-Diasty and Salem 2007).

From Tables 2 and 3 it was clear that Mucor spp., Penicillium vercosaum and Cladosporium spp. were isolated from the examined meat products samples at varying percentages ranged from $13.33-26.66 \%$.The growth of Penicillum spp. on the surface of meat-based dry fermented sausage provides them with a protective effect against some undesirable microorganisms. Penicillium also acts as antioxidant, minimizes the risk of excessive drying, and it is responsible for flavor development due to the decomposition of proteins, free fatty acids and lactic acid (Ludemann, et al., 2004). The predominant species of yeasts isolated from beef luncheon, chicken luncheon, turkey luncheon, salami, rose beef, basterma and pastrami were Candida spp. followed by Rhodotorula spp., and then Crypotococcus spp. From Tables 4 and 5 for mould isolates it was clear that out of 4 isolates of Penicillium vercoasum 3 showed proteolytic activity while 4 isolates showed lipolytic activity. Two isolates of Mucor spp., 1 showed proteolytic activity while the two isolates showed lipolytic 
activity and out of 6 isolates of Cladosporium spp. 3 showed proteolytic activity while 4 isolates showed lipolytic activity. On the other hand from tables 6 and 7 it is evident that out of 108 isolates of Candida spp., 71 showed proteolytic activity while 91 isolates showed lipolytic activity. Out of 16 Cryptococcus spp., 11 showed proteolytic activity while 13 isolates showed lipolytic activity and out of 42 Rhodotorula spp., 31 showed proteolytic activity while 31 isolates showed lipolytic activity. From the previous results it is obvious that lipolytic activity is more predominant than proteolytic activity. Sayed (1999); Nasser (2002); El-Diasty(2004) stated that both Aspergillus and Penicillium spp. as well as Candida spp. were of proteolytic and lipolytic activities. Most isolates of A.flavus, A.niger, Cladosporium spp., Mucor spp. and Penicillium were having a proteolytic activity with different strength. Geotrichium spp. where having a lipolytic activity. Also most isolates of Candida lipolytica, C.parapasillosis were having lipolytic activity (El-Diasty and Salem, 2007).

Exposure to mycotoxins can produce both acute and chronic toxicities ranging from death to deleterious effects upon the central nervous, cardiovascular and pulmonary systems and upon the alimentary tract. The ability of some mycotoxins to compromise the immune response and consequently, to reduce resistance to infectious disease is now widely considered to be the most important effect of mycotoxins particularly in developing countries (FAO, 2001).

\section{CONCLUSION}

In spite of presence of different mould and yeast species from meat products having been isolated these kinds of food appear to be favourable for all people of all ages. The spoilage potential of yeast and mould appears to be related to their proteolytic and lipolytic activity so, mould and yeast contaminations as well as their proteolytic and lipolytic activity should be monitored routinely for food safety and to reduce human risk in public health.

\section{REFERENCES}

Abdel-Rahman, H.A.; Yossef, H. and Hefnawey, Y. (1984): Mycolocical quality of meat products in Egypt. Assiut Vet. Med. J. 12(24): 153-159.

Aikins, D. and Norman, J. (1998): Mycotoxins and food safety. Nutrition and Food Sci. 5:260. 
APHA (1992): Compendium of Methods for the Microbiological Examination of Food. $3^{\text {rd }}$ Ed. APHA Technical committee on microbiological methods for foods, Washington, D.C., USA.

Bailey, W.R. and Scott, E.G. (1998): Diagnostic Microbiology. A Textbook for the isolation and identification of pathogenic microorganisms. The Mosby Company Saint Louis.

Berwal, J.S. and Dinchev, D. (1991): Study of the mycoflora during the natural commertial fermentation of raw dry sausages. Mecoe mecni Prodykti 1: 34-37.

CAST (Council for Agricultural Science and Technology)(2003): Mycotoxins: Risks in plant,animal and human systems. Task force report.139. CAST, Ames, IA.

Cavaliere, G.; Foglia, P.; Pastorini, E.; Samperi, R. and Lagana, A. (2006): Liquid chromatography/ Tandem mass spectrometric confirmatory method for determining aflatoxin $\mathrm{M}_{1}$ in cow milk comparison between electrospray and at atmospheric pressure photoionization sources J. of Chromatograpgy A. 1101: 69-78.

Cook, P.E. (1995): Fungal Ripened Meats and Meat Products. In Fermented Meats, G. Campbell-Platt, P.E. Cook(Eds), Blackie Academic and Professional, London P 110.

El-Diasty, E.M. (2004): Study on mycological quality of fish Ph.D. Thesis, Fac. Vet. Med., Cairo Univ., Beni-suef branch.

El-Diasty, E.M. and Salem, R.M. (2007): Incidence of Lipolytic and proteolytic fungi in some milk products and their public health significance. J. of App. Science Research, 3(12): 1684-1688.

Ercolini, D.; Russo, F.; Torrieri, E.; Masi, P. and Villani, F. (2006): Changes in the spoilage-related microbiota of beef during refrigerated storage under different packaging conditions. Appl. Environ. Microbiol. 72: 4663-4671.

FAO (2001): Manual on the application of the HACCP system in mycotoxin prevention and control. FAO/IAEA training and reference center for food and pestiside control 1-25.

Finegold, S.M. and Martin, W.J. (1982): Diagnostic Microbiology $6^{\text {th }}$ Ed. The C.V. Mosby Co. Toronto, London.

Garcia, S. and Heredia, N. (2006): Mycotoxins in Mexico: Epidemiology, management and control stralegies. Mycopathology 162: 255-264.

Koburger, J.A. and Jacger, K.E. (1987): " Specific and sensitive plate assay for bacterial lipases". Appl. Environ. Microbiol., 53: 211.

Koneman, E.W.; Roberts, C.D. and Wrright, S.E. (1978): Practical laboratory Mycology $2^{\text {nd }}$ Ed., The Williams and Wilkins Co., Baltimore. 
Lashin, E.M.D. (2003): Study on mycological quality of fish Ph. D. Thesis, Fac. Vet. Med. Cairo Univ., Beni Suef Branch.

Lopez Diaz, T.M.; Santos, J.A.; Gracia lopez, M.I. and Otero, A. (2001): Surface mycoflora of Spanish fermented meat sausage and toxigenicity of Penicillium isolates. International J. Food Microbiol. 68: 69-74.

Ludemann, V.; Pose, G.; Pollio, M.L. and Segura, J. (2004): Determination of growth characteristics and lipolytic and proteolytic activities of penicillium strains isolated from Argentinean salami. International J. Food Microbiol. 96: 13-18

Nasser, L.A. (2002): Mycological status of imported canned fish consumed in Saudia Arabia with special reference to proteolytic activity. Assiut Vet. Med. J., 47: 125-130.

O'reilly, T. and Day, D.F. (1983): Effects of culture conditions on protease production by Aeromonas hydrophila." Appl. Environ., 45: 1132.

Pitt, J.I. (2000): Toxigenic fungi and mycotoxin cited from Br. Med. Bull. 56(1): 184-192.

Pitt, J.I. and Hocking, A.D. (1997): "Fungi and Food Spoilage Book" 3rd Ed., Academic press, New York, London, Toronto, Montreal, Tokyo.

Sabbioni, G. and Sepai, O. (1998): Determination of human exposure to aflatoxins.183-226. In: Mycotoxinsin Agriculture and Food Safety. K.K. Sinha and D. Bhatnagar (ed) Marcel Dekker Inc., New York.

Sayed, A.A.K. (1999): Proteolytic fungi in some meat products: Their incidence and methods for inhibition. M.V. Sc. Thesis, Fac. Of Vet. Med., Assuit Univ. Egypt.

Surve, A.N.; Sherikar, A.T.; Bhilegaonkar, K.N. and Karkare, U. (1991):

Preservative effect of combinations of acetic acid with lactic or propionic acid on buffalo meat stored at refrigeration temperature. Meat Sci. 29: 309-322.

Takahashi-Ando, M.; Ohsato, S.; Shibata, T.; Hamamoto, H.; Yamaguchi, I. and Kimura, M. (2004): Metabolism of zearalenone genetically modified organisms expressing the detoxification gene from clonostachys tosca Appl. Environ. Microbiol. 70(6)3239-3245.

Viljoen, B.C. and Greyling, T. (1995): Yeasts associated with cheddar and Gouda making. Int. J. Food Microbiol., 28: 79-88. 